\title{
ELEMENTAL CONTENT AND LEAD-STRONTIUM ISOTOPE CHARACTERIZATION OF WINE
}

\author{
FLORIN DUMITRU BORA ${ }^{a}$, ALINA DONICI ${ }^{a}$, ANAMARIA CĂLUGĂR ${ }^{b}$, \\ PETER SOMSAI $^{c}$, DOINA CLAPA ${ }^{c}$, EMESE GAL ${ }^{d}$, CLAUDIU IOAN BUNEA $^{b}$ \\ ADELINA DUMITRAȘ ${ }^{\mathrm{b}, *}$
}

\begin{abstract}
The ICP-MS technique was used to determine elemental composition ( $\mathrm{Pb}, \mathrm{Sr}, \mathrm{Cd}, \mathrm{Ni}, \mathrm{Co}, \mathrm{Cu}, \mathrm{Ni}, \mathrm{Hg}, \mathrm{As}, \mathrm{Cr}$ ) of wines (Muscat Ottonel, Fetească Albă, Fetească Regală, Fetească Neagră, Merlot and Cabernet Sauvignon) produced during three consecutive years (2014-2016) in Dealu Bujorului Vineyard. The determination of ${ }^{206} \mathrm{~Pb} / 207 \mathrm{~Pb},{ }^{208} \mathrm{~Pb} /{ }^{206} \mathrm{~Pb},{ }^{206} \mathrm{~Pb} /{ }^{207} \mathrm{~Pb}$ and ${ }^{87} \mathrm{Sr} /{ }^{86} \mathrm{Sr}$ isotopes from wines was performed for establishing reliable markers for wine geographical origin. For all tested wine samples, the toxic metals contents were found in quantities below the limits imposed by legislation. The highest concentration of heavy metals $(\mathrm{Cd}$ and $\mathrm{Pb})$ was found in red wine Cabernet Sauvignon [Cd $(0.14 \pm 0.01 \mu \mathrm{g} / \mathrm{L})(2013)]$, followed by the same variety of wine from 2012 [Cd $(0.14 \pm 0.03 \mu \mathrm{g} / \mathrm{L})$ ], in case of $\mathrm{Pb}$ the highest concentration was recorded by Merlot $[\mathrm{Pb}(54.33 \pm 1.00 \mu \mathrm{g} / \mathrm{L})(2011)]$ followed by the same variety of wine but from 2012 [Cd $(51.20 \pm 1.19 \mu \mathrm{g} / \mathrm{L})$. Concerning the concentration of the elements in the white wine, it can be noticed that they recorded close concentration as red wine, Muscat Ottonel [Cd $(0.12 \pm 0.01 \mu \mathrm{g} / \mathrm{L})(2011)]$, Feteasca Alba [Cd $(0.12 \pm 0.01 \mu \mathrm{g} / \mathrm{L})(2012)]$, in case of $\mathrm{Pb}$ from white wines the highest concentration was recorded by Feteasca Alba $[\mathrm{Pb}(52.07 \pm 0.50 \mu \mathrm{g} / \mathrm{L})$ (2012)], Feteasca Regala [Cd $(52.29 \pm 1.00 \mu \mathrm{g} / \mathrm{L})(2012)]$. The highest mean of ${ }^{87} \mathrm{Sr} /{ }^{86} \mathrm{Sr}$ isotopic ratio was obtained at Feteasca Neagra variety $[0.726 \pm 0.004(0.575 \%, 2014)]$ and Muscat Ottonel variety $[0.723 \pm 0.003(0.416 \% 2016)]$. A possible explanation for the higher mean of ${ }^{87} \mathrm{Sr} /{ }^{86} \mathrm{Sr}$ isotopic ration for wine can be
\end{abstract}

a Research Station for Viticulture and Enology Targu Bujor, 65 G-ral Eremia Grigorescu Street, RO-805200, Galați, Romania.

b University of Agricultural Sciences and Veterinary Medicine, Department of Horticulture and Landscaping, 3-5 Mănăştur Street, RO-400372 Cluj-Napoca, Romania.

c University of Agricultural Sciences and Veterinary Medicine, Station of Horticulture Research, Cluj-Napoca, 5 Horticultorilor Street, RO-400457, Cluj-Napoca, Romania.

d Babeş-Bolyai University, Faculty of Chemistry and Chemical Engineering, 11 Arany Janos Street, RO-400028, Cluj-Napoca, Romania.

* Corresponding author: dumitrasadelina@gmail.com 
the mineral consistency of the vineyard soil and its different eco-climatic conditions. ${ }^{206} \mathrm{~Pb} /{ }^{207} \mathrm{~Pb}$ isotopic ratios in the analyzed wine samples indicated traces of pollution originated in automobile emissions. $\left({ }^{206} \mathrm{~Pb} /{ }^{207} \mathrm{~Pb}=1.1000\right.$ 1.1400). The lowest mean ${ }^{208} \mathrm{~Pb} / 206 \mathrm{~Pb}$ and ${ }^{206} \mathrm{~Pb} /{ }^{204} \mathrm{~Pb}$ isotopic ratios was obtained at Muscat Ottonel variety $[2.141 \pm 0.007(0.346 \% 2015)$ and $17.469 \pm 0.016(0.094 \% 2014)]$. The results confirm that the elemental profile and ${ }^{207} \mathrm{~Pb} /{ }^{206} \mathrm{~Pb},{ }^{208} \mathrm{~Pb} /{ }^{206} \mathrm{~Pb},{ }^{204} \mathrm{~Pb} / 206 \mathrm{~Pb},{ }^{87} \mathrm{Sr} /{ }^{86} \mathrm{Sr}$ isotope ratio can be used to track the geographical origin of wine, discriminate between wine production regions, and can be used to characterize wine terroirs for forensic purpose.

Keywords: geographical origin, elemental content, ${ }^{207} \mathrm{~Pb} /{ }^{206} \mathrm{~Pb},{ }^{208} \mathrm{~Pb} /{ }^{206} \mathrm{~Pb}$, ${ }^{204} \mathrm{~Pb} /{ }^{206} \mathrm{~Pb},{ }^{87} \mathrm{Sr}{ }^{86}$ Srisotope ratio.

\section{INTRODUCTION}

Wine quality testing is made by using the state of the art of analytical techniques, because of the European community demand to establish an integrated approach on beverage control. The main purpose is a high level of wines safety within the European Union through so called soil-to-grape-to-wine-to-glass measuring and monitoring, ensuring the effective functioning of the European market [1].

Quality of wine is not only a gift of nature, but also the result of a wide range of technological intervention throughout the entire production process [2]. Current oenological research defines wine quality in relation to its chemical composition, pharmacological properties and health safety [3]. It is very important to monitor food products and beverage, including wines, for heavy metal contamination and assess the source of food contamination. Must and wine has a primary content of elemental composition due to natural transfer soil-root-grape-wine $[4,5]$ and a secondary content due to natural $[6$, 7] and artificial contamination [8,9]. The natural content of elemental composition of wine and of other beverage is affected and overlapped by the artificial contamination [10].

Quantification of several elements in wines can validate the original authentication $[8,9,11,12]$, the potential toxicity and role in human diet $[6,13$, $14]$, the effect on wine stability and organoleptic characteristics [15, 16, 17].

Wine is a source for essential elements which might improve human health, but it may also expose the consumer to undesirable levels and types of heavy metals when it is consumed regularly and in large amount over a long period of time [6]. The concern in human exposure to the metal 
content of various beverages received a raising attention, since the consumption of wines in large volumes, significantly contribute to the daily dietary trace element intake by humans and so far there have not been a precise characterization of the impact of a number and the amounts of metals found in different drinks (alcoholic and non-alcoholic) on human health $[13,18]$. In the production of wines, the quality control checks have to be brought to ensure that the consumer is protected and possible sources of contaminations are traced. The origin of $\mathrm{Cu}$ in wines is due to copper-based sprays used in vineyards, whereas the As, $\mathrm{Cd}$, and $\mathrm{Pb}$ contents reflect the differences in grape variety, environmental factors and the wine-processing methods [11]. The $\mathrm{Pb}, \mathrm{Hg}$ and $\mathrm{Cd}$ are undoubtedly considered toxic and should be monitored all the time, but also $\mathrm{Cu}, \mathrm{Ni}, \mathrm{Cr}$, $\mathrm{V}, \mathrm{Zn}, \mathrm{Ag}$, and $\mathrm{Al}$, which in high concentrations may impart a certain toxicity $[6,13,18]$. The determination of $\mathrm{Cd}, \mathrm{Pb}, \mathrm{Cu}$ and $\mathrm{Zn}$ in wines is of great interest from oenological and toxicological points of view and correct knowledge of these parameters is required by the law. The Organisation International de la Vigne et du Vin (OIV) established Maximum Acceptable Limits (M.A.L.) for only a few elements in wine (Pb, Cd, $\mathrm{Cu}, \mathrm{Na}, \mathrm{Zn}, \mathrm{Ag}, \mathrm{As}$, $\mathrm{F}, \mathrm{Br}, \mathrm{F}$, and $\mathrm{B}$ [1]. The determination of toxic, such as $\mathrm{Cd}, \mathrm{As}$ and $\mathrm{Pb}$ and essential trace elements, like $\mathrm{Cu}$, in wines is an important and challenging analytical task, which requires multi-element methods of good selectivity, sensitivity and robustness [11, 19, 20].

Heavy metals are defined as those with a higher density than 5 $\mathrm{mg} / \mathrm{l}$, but the collective term now includes $\mathrm{As}, \mathrm{Cd}, \mathrm{Cr}, \mathrm{Cu}, \mathrm{Fe}, \mathrm{Pb}, \mathrm{Mn}, \mathrm{Hg}$, $\mathrm{Mo}, \mathrm{Ni}, \mathrm{V}$ and $\mathrm{Zn}[6,21]$. Elements like $\mathrm{K}, \mathrm{Ca}, \mathrm{Mg}, \mathrm{Fe}, \mathrm{Cu}, \mathrm{Zn}$ and $\mathrm{Cr}$ are expected to be found in wines due to their high intercellular content and physiological roles and processes in plant, in wine yeasts and humans [6].

The content of elements such as $\mathrm{Cu}, \mathrm{Fe}, \mathrm{Mn}$, and $\mathrm{Zn}$ were found in higher amounts in red grapes than white grapes and in lower amounts in wines than grapes [22]. Some elements may be lost through winemaking process, but the exposure to precipitants (bentonites) and containers may contribute to the quantity of some metals in wines [23].

Studies of isotopic ratios of heavy metals such $\mathrm{Pb}$ and $\mathrm{Sr}$ provide additional information on the geographical origin of wines, due to fact that plants inherit the isotopic signature of both elements from the geological and pedological environment [24].

Lead isotopic analysis of wines from France (Bordeaux) showed that the lead content in wines changed over time and reflected the dominant source of atmospheric lead pollution in southern of France [25]. Other researchers have found that lead isotopic compositions in wine may not always reflect those of leaded petrol, but reflect the isotopic signature of 
local, dominant metallurgical industries [26, 27]. These studies confirm atmospheric deposition as being the dominant contributor to the lead total concentration and isotopic composition from wines. Some studies have shown that contamination from tin-lead foil capsules in the presence of corrosion and cork disintegration can dominate the source of lead from wines [28]. Other researchers have attributed the lead in wine to machinery or additives used during the winemaking process where environmental contamination in this case is low [29].

Isotopic ratios of heavy elements of geological interest, such as ${ }^{87} \mathrm{Sr} /{ }^{86} \mathrm{Sr},{ }^{207} \mathrm{~Pb} /{ }^{206} \mathrm{~Pb},{ }^{208} \mathrm{~Pb} /{ }^{206} \mathrm{~Pb}$ and ${ }^{204} \mathrm{~Pb} /{ }^{206} \mathrm{~Pb}$ have raised an interest in tracking regional provenance of wine $[30,31]$. The winemaking process of red and white wines does not affect the ${ }^{87} \mathrm{Sr} / 86 \mathrm{Sr}$ ratio of wine, so this allows to link the Sr-isotopes of wine to those of the vineyard substratum [32, 33].

Inductively coupled plasma mass spectrometry (ICP-MS) is a multielement technique frequently used for the elemental analysis of different wines (young and aged, red, rose and white, table and fortified, dry and sweet wines) in (semi)quantitative mode providing high selectivity, sensitivity and lower detection limits than other multi-element techniques $[34,35]$. Also, ICP-MS was used for lead and strontium isotopic composition determination in several types of wines [36].

The purpose of this study is to determine the elemental composition $(\mathrm{Cd}, \mathrm{Pb}, \mathrm{U}, \mathrm{Hg}, \mathrm{As}, \mathrm{Sr}, \mathrm{Co}, \mathrm{Cu}, \mathrm{Ni}$ and $\mathrm{Cr}$ ) of white wines (Muscat Ottonel, Fetească albă, Fetească regală) and red wines (Fetească neagră, Merlot, Cabernet Sauvignon) from Dealu Bujorului Vineyard, using the ICP-MS technique (method approved by L'Organisation International du Vie et Vin). The results of this study may highlight the elemental composition of wine samples, assess the ability to discriminate wines by geographical origin and also complete the data regarding strontium $\left({ }^{87} \mathrm{Sr} /{ }^{86} \mathrm{Sr}\right)$ and lead $\left({ }^{206} \mathrm{~Pb} /{ }^{204} \mathrm{~Pb}\right.$, ${ }^{207} \mathrm{~Pb} /{ }^{204} \mathrm{~Pb},{ }^{208} \mathrm{~Pb} /{ }^{204} \mathrm{~Pb}$ ) isotope ratios in wines from Dealu Bujorului Vineyard (Galati county, Romania).

\section{RESULTS AND DISCUSSION}

\section{Wine Mineral Content}

Table 1 summarizes the total content of $\mathrm{Cd}, \mathrm{Pb}, \mathrm{U}, \mathrm{Hg}, \mathrm{As}, \mathrm{Sr}, \mathrm{Co}$, $\mathrm{Cu}, \mathrm{Ni}$ and $\mathrm{Cr}$ in wine samples. In general, these elements are present in wine due to their extraction from grapes during the maceration period [37]. In grapes, these elements may occur by bioaccumulation in the vine plant from the soil, or they could originate from the pesticide agents used in plant 
protection. During the maceration, extracted elements are absorbed at the cell membrane of yeast, and afterward, their declines as a result of precipitation together with the yeast cell or precipitation in complexation reactions. The contact of wine with equipment, the addition of fining agents, or the changing of filters, during post fermentation processes could increase the content of elements [37].

The mean contents of $\mathrm{Cd}, \mathrm{Pb}$ and $\mathrm{U}$ were $0.10 \pm 0.01 \mu \mathrm{g} / \mathrm{L}, 41.51 \pm 1.05$ $\mu \mathrm{g} / \mathrm{L}$ and $0.26 \pm 0.03 \mu \mathrm{g} / \mathrm{L}$, in case of $\mathrm{Pb}$ and $\mathrm{U}$ the highest concentrations were recorded in Feteasca regala [52.29 $\pm 1.00 \mu \mathrm{g} / \mathrm{L} \mathrm{Pb}(2014) ; 51.39 \pm 1.81 \mu \mathrm{g} / \mathrm{L} \mathrm{Pb}$ (2015) and $0.38 \pm 0.03 \mu \mathrm{g} / \mathrm{L} U(2014) ; 0.40 \pm 0.01 \mu \mathrm{g} / \mathrm{L} U(2015)]$ while $\mathrm{Cd}$ was recorded the highest concentrations in Cabernet Sauvignon $[0.14 \pm 0.01 \mu \mathrm{g} / \mathrm{L}$

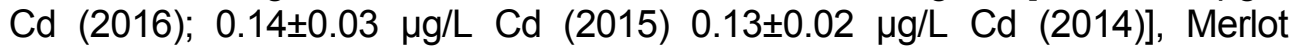
$[0.13 \pm 0.02 \mu \mathrm{g} / \mathrm{L} \mathrm{Cd}(2014)]$ Feteasca Neagra [0.13 $\pm 0.01 \mu \mathrm{g} / \mathrm{L} \mathrm{Cd}(2014)]$. The highest concentrations of heavy metals $\mathrm{Cd}$ and $\mathrm{Pb}$ were found in the red wine Cabernet Sauvignon [Cd $(0.14 \pm 0.01 \mu \mathrm{g} / \mathrm{L}$ produced in 2013)], followed by the same variety of wine but produced in 2012 [Cd $(0.14 \pm 0.03 \mu \mathrm{g} / \mathrm{L})]$; in the case of $\mathrm{Pb}$ the highest concentration was recorded in Merlot $[\mathrm{Pb}(54.33 \pm 1.00 \mu \mathrm{g} / \mathrm{L})$ (2011)] followed by the same variety of wine but from 2012 [Pb $(51.20 \pm 1.19$ $\mu \mathrm{g} / \mathrm{L})$. Concerning the concentration of the elements in the white wine, it can be noticed that the recorded values are close to the red wine, e.g. Muscat Ottonel [Cd (0.12 $\pm 0.01 \mu \mathrm{g} / \mathrm{L})(2011)]$, Feteasca Alba [Cd $(0.12 \pm 0.01 \mu \mathrm{g} / \mathrm{L})$ (2012)]; in the case of $\mathrm{Pb}$ from white wines the highest concentration was recorded in Feteasca Alba [Pb $(52.07 \pm 0.50 \mu \mathrm{g} / \mathrm{L})(2012)]$, Feteasca Regala $[\mathrm{Pb}(52.29 \pm 1.00 \mu \mathrm{g} / \mathrm{L})(2012)]$. These results appear compatible with some other studies [37] reporting $0.25 \mu \mathrm{g} / \mathrm{L}(\mathrm{Cd}), 46.00 \mu \mathrm{g} / \mathrm{L}(\mathrm{Pb}), 0.11 \mu \mathrm{g} / \mathrm{L}(\mathrm{U})$, [8] $0.14 \mu \mathrm{g} / \mathrm{L}(\mathrm{Cd}), 47.80 \mu \mathrm{g} / \mathrm{L}(\mathrm{Pb})$, but in some other reported results [38], the concentration of $\mathrm{Cd}$ appeared significantly higher $(10.60 \mu \mathrm{g} / \mathrm{L})$, while the reported values for $\mathrm{Pb}$ concentration appeared significantly lower $(15.70 \mu \mathrm{g} / \mathrm{L})$.

The concentration of $\mathrm{Hg}$ has recorded values between [0.58 \pm 0.04 $\mu \mathrm{g} / \mathrm{L}$ Muscat Ottonel (2014); 0.51 $\pm 0.04 \mu \mathrm{g} / \mathrm{L}$ Feteasca Neagra (2014)] and $[0.24 \pm 0.04 \mu \mathrm{g} / \mathrm{L}$ Feteasca Neagra (2016); $0.19 \pm 0.02 \mu \mathrm{g} / \mathrm{L}$ Feteasca Neagra (2015)] with an average values of $0.28 \pm 0.03 \mu \mathrm{g} / \mathrm{L}$. In this case, Fetească regală $(<0.13 \mu \mathrm{g} / \mathrm{L})$ and Merlot $(<0.13 \mu \mathrm{g} / \mathrm{L})$ have registered the values below the detection limit. Although the highest concentration was recorded in white wines, the average data shows that the red wines have the highest values $0.22 \mu \mathrm{g} / \mathrm{L}$, compared to white wines $0.18 \mu \mathrm{g} / \mathrm{L}$ (Table 1 ). The results agree with those made in Romania [20] for Sauvignon Blanc $0.56 \mu \mathrm{g} / \mathrm{L}$, Feteasca Alba $0.22 \mu \mathrm{g} / \mathrm{L}$ and Riesling $0.16 \mu \mathrm{g} / \mathrm{L}$.

As and $\mathrm{Sr}$ content in wine ranged from $[16.74 \pm 4.30 \mu \mathrm{g} / \mathrm{L}$ As; $6.20 \pm 0.23 \mu \mathrm{g} / \mathrm{L} \mathrm{As}]$ and $[277.49 \pm 3.64 \mu \mathrm{g} / \mathrm{L} \mathrm{Sr} ; 114.08 \pm 6.44 \mu \mathrm{g} / \mathrm{L} \mathrm{Sr}]$ with an average values of $10.81 \pm 0.61 \mu \mathrm{g} / \mathrm{L}$ As and $205.29 \pm 5.63 \mu \mathrm{g} / \mathrm{L} \mathrm{Sr}$. In both 
cases the maximum concentration were recorded in red wines Cabernet Sauvignon [16.74 $\pm 4.30 \mu \mathrm{g} / \mathrm{L}$ As (2016); 14.41 $\pm 2.75 \mu \mathrm{g} / \mathrm{L}$ As (2015)] and Feteasca Neagra [277.49 $\pm 3.64 \mu \mathrm{g} / \mathrm{L}$ Sr $(2016) ; 263.81 \pm 2.28 \mu \mathrm{g} / \mathrm{L} \mathrm{Sr}$ (2015)] while the lowest concentrations were recorded in white wines Feteasca Alba [6.42 $\pm 0.87 \mu \mathrm{g} / \mathrm{L}$ As (2015); $6.20 \pm 0.23 \mu \mathrm{g} / \mathrm{L}$ As (2014)] and Muscat Ottonel [149.12 $\pm 5.50 \mu \mathrm{g} / \mathrm{L} \mathrm{Sr}(2014) ; 114.08 \pm 6.44 \mu \mathrm{g} / \mathrm{L} \mathrm{Sr}(2015)]$. The average data shows that the red wines have the highest values [13.22 $\mu \mathrm{g} / \mathrm{L}$ As and $228.44 \mu \mathrm{g} / \mathrm{L} \mathrm{Sr}$ compared to white wines values $[9.25 \mu \mathrm{g} / \mathrm{L}$ As and $171.95 \mu \mathrm{g} / \mathrm{L} \mathrm{Sr}$ (Table 1). The results are comparable with those obtained in Serbia [8] $16.1 \mu \mathrm{g} / \mathrm{L}$ (As) for red wines and 9.46 (As) $\mu \mathrm{g} / \mathrm{L}$ for white wines, in Macedonia [38] $11.7 \mu \mathrm{g} / \mathrm{L}$ (As), in Romania [20] $21.12 \mu \mathrm{g} / \mathrm{L}$ (As) and $154.90 \mu \mathrm{g} / \mathrm{L}(\mathrm{Sr})$, and higher compared to the results obtained in Italy [39] $2.91 \mu \mathrm{g} / \mathrm{L}$ for As, but for Sr the results obtained are significantly lower compared to the results obtained in Italy [39] $1340 \mu \mathrm{g} / \mathrm{L}(\mathrm{Sr})$.

Concentration of Co has recorded values between $[6.74 \pm 0.48 \mu \mathrm{g} / \mathrm{L}$ Fetească regală (2015); 6.28 $\pm 0.28 \mu \mathrm{g} / \mathrm{L}$ Feteasca Alba (2014)] and $[3.55 \pm 0.39 \mu \mathrm{g} / \mathrm{L}$ Muscat Ottonel $(2015) ; 3.71 \pm 0.21 \mu \mathrm{g} / \mathrm{L}$ Feteasca Neagra (2014)] with an average value of $4.54 \pm 0.21 \mu \mathrm{g} / \mathrm{L}$. The average data shows that the red wines have the highest values $[6.75 \mu \mathrm{g} / \mathrm{L} \mathrm{Co}]$ compared to white wines values [2.97 $\mu \mathrm{g} / \mathrm{L} \mathrm{Co}$ (Table 1$)$. The results agree with other studies made in Macedonia [37, 38] $3.9 \mu \mathrm{g} / \mathrm{L}$ and $13.90 \mu \mathrm{g} / \mathrm{L}$ for $\mathrm{Co}$, and in Serbia [8] $3.89 \mu \mathrm{g} / \mathrm{L}$ (Co) for red wines and 3.96 (Co) $\mu \mathrm{g} / \mathrm{L}$ for white wines.

The mean contents of $\mathrm{Ni}$ and $\mathrm{Cr}$ were $573.11 \pm 2.85 \mu \mathrm{g} / \mathrm{L} \mathrm{Ni}$ and $660.94 \pm 2.72 \mu \mathrm{g} / \mathrm{L} \mathrm{Cr}$, in case of $\mathrm{Ni}$ the highest concentrations were recorded in Feteasca Neagra [747.37 $\pm 3.35 \mu \mathrm{g} / \mathrm{L} \mathrm{Ni}(2014)]$ while $\mathrm{Cr}$ was recorded the highest concentrations in Muscat Ottonel [923.62 $\pm 2.05 \mu \mathrm{g} / \mathrm{L} \mathrm{Cr}(2014)]$. In Fetească regală was recorded the lowest concentration of Ni $[239.81 \pm 1.34$ $\mu \mathrm{g} / \mathrm{L} \mathrm{Ni} \mathrm{(2016)]} \mathrm{while} \mathrm{in} \mathrm{Feteasca} \mathrm{Neagra} \mathrm{was} \mathrm{recorded} \mathrm{the} \mathrm{lowest}$ concentration of $\mathrm{Cr}[323.92 \pm 4.09 \mu \mathrm{g} / \mathrm{L} \mathrm{Cr}(2015)]$. The results agree with those reported in Turkey [40] $520 \mu \mathrm{g} / \mathrm{L} \mathrm{Ni}$, in Romania [41] 147.73 $\mu \mathrm{g} / \mathrm{L} \mathrm{Cr}$ and significantly higher than the ones obtained in Serbia [8] $5.49 \mu \mathrm{g} / \mathrm{L}(\mathrm{Cr})$ red wines and $6.56(\mathrm{Cr}) \mu \mathrm{g} / \mathrm{L}$ white wines, in Italy [39] $54.57 \mu \mathrm{g} / \mathrm{L}(\mathrm{Ni})$ and $19.68 \mu \mathrm{g} / \mathrm{L}$ (Cr), in Macedonia [38] $32.10 \mu \mathrm{g} / \mathrm{L}(\mathrm{Cr})$ and $10.20 \mu \mathrm{g} / \mathrm{L}(\mathrm{Cr})$. The results indicated that Romanian wines are moderately rich in $\mathrm{Cr}$ (Table 1).

The concentration for $\mathrm{Cu}$ ranged from $0.48 \pm 0.03 \mathrm{mg} / \mathrm{L}$ to $0.91 \pm 0.05$ $\mathrm{mg} / \mathrm{L}$, with average values of $0.72 \pm 0.04 \mathrm{mg} / \mathrm{L}$, the latter value approaching the law limit $(1 \mathrm{mg} / \mathrm{L})$. The six samples [Fetească regală $0.85 \pm 0.07 \mathrm{mg} / \mathrm{L}$ (2014), Feteasca Regala 0.82 $\pm 0.06 \mathrm{mg} / \mathrm{L}$ (2016), Feteasca Neagra $0.80 \pm 0.01 \mathrm{mg} / \mathrm{L}$ (2016), Cabernet Sauvignon $0.79 \pm 0.41 \mathrm{mg} / \mathrm{L}$ (2014), Feteasca Alba $0.77 \pm 0.08 \mathrm{mg} / \mathrm{L}$ (2015) and Feteasca Neagra $0.71 \pm 0.03$ $\mathrm{mg} / \mathrm{L}$ (2014)] showed relatively high concentration of $\mathrm{Cu}$. Wide rages for $\mathrm{Cu}$ 
concentration in wines have been previously found and reported by other researchers in Brazil [42] 0.056-0.764 mg/L Cu, in Hungary [43] 0.031$0.313 \mathrm{mg} / \mathrm{L} \mathrm{Cu}$, in Italy [44] 0.50-1.00 mg/L Cu and in Greece [45] 0.076$0.114 \mathrm{mg} / \mathrm{L} \mathrm{Cu}$ (Table 1).

Examining the factors which influenced the content of metals in wines, it can be seen that the content in $\mathrm{Cd}, \mathrm{Pb}, \mathrm{U}, \mathrm{Hg}, \mathrm{Sr}, \mathrm{Co}, \mathrm{Ni}$ and $\mathrm{Cr}$ was significantly influenced by the Variety, Years and Variety $x$ Years factors, while As and Cu content was significantly influenced only by the Variety factors.

Relating the obtained results [Cd average $0.10 \pm 0.01 \mu \mathrm{g} / \mathrm{L}(0.1 \mathrm{mg} / \mathrm{kg}$ M.L.A. = Maximum Limit Allowed) $\mathrm{Pb}$ average $41.51 \pm 1.05 \mu \mathrm{g} / \mathrm{L}(0.15 \mathrm{mg} / \mathrm{kg}$ M.A.L); As average $10.81 \pm 0.61 \mu \mathrm{g} / \mathrm{L}(0.2 \mathrm{mg} / \mathrm{kg}$ M.A.L); Cu average $0.72 \pm 0.04$ $\mathrm{mg} / \mathrm{L}$ (1 $\mathrm{mg} / \mathrm{kg}$ M.A.L) to national and international legislation we may say that the wines from Dealu Bujorului vineyard fall within the limits set by legislation (Table 1).

\section{${ }^{206} \mathrm{~Pb} /{ }^{207} \mathrm{~Pb},{ }^{208} \mathrm{~Pb} /{ }^{206} \mathrm{~Pb},{ }^{206} \mathrm{~Pb} / 204 \mathrm{~Pb},{ }^{87} \mathrm{Sr} /{ }^{86} \mathrm{Sr}$, isotope ratio from wine samples}

In Central Europe, the lead isotopic ratio, as signatures of pollution sources, ranges from relatively high ${ }^{206} \mathrm{~Pb} /{ }^{207} \mathrm{~Pb}$ ratios (natural $\mathrm{Pb}$, coals, fly ashes, ${ }^{206} \mathrm{~Pb} /{ }^{207} \mathrm{~Pb}=1.1700-1.2200$ ) to low ${ }^{206} \mathrm{~Pb} /{ }^{207} \mathrm{~Pb}$ values (gasoline, petrol combustion, $\left.{ }^{206} \mathrm{~Pb} / 207 \mathrm{~Pb}=1.0600-1.1400\right)[20,27]$.

The $\mathrm{Pb}$ isotopes ratio for the selected wines (Table 2 ) varies in range between 1.13896-1.12545 $\left({ }^{206} \mathrm{~Pb} /{ }^{207} \mathrm{~Pb}\right), 2.13857-2.12126\left({ }^{208} \mathrm{~Pb} /{ }^{206} \mathrm{~Pb}\right)$ and 17.30857-17.44944 $\left({ }^{206} \mathrm{~Pb} / 204 \mathrm{~Pb}\right)$ with average $1.13269\left({ }^{206} \mathrm{~Pb} /{ }^{207} \mathrm{~Pb}\right), 2.12824$ $\left({ }^{208} \mathrm{~Pb} /{ }^{206} \mathrm{~Pb}\right)$ and 17.42213 . Regarding ${ }^{206} \mathrm{~Pb} /{ }^{207} \mathrm{~Pb}$ isotope ratios based on analyses it can be concluded that the wine obtained from wine varieties grown in the Dealu Bujorului vineyards show traces of pollution originating from automobile emissions $\left({ }^{206} \mathrm{~Pb} /{ }^{207} \mathrm{~Pb}=1.1000-1.1400\right)$. The obtained isotope ratio values are comparable with other Romanian wines [20] (1.1100 to 1.2000) and Brazilian wines [36] (1.1440 to 1.1820).

The highest values of ${ }^{208} \mathrm{~Pb} /{ }^{206} \mathrm{~Pb}$ and ${ }^{206} \mathrm{~Pb} /{ }^{204} \mathrm{~Pb}$ were recorded for wines obtained from Muscat Ottonel variety from $2012(2.13857 \pm 0.00699$ $\left.[0.32697]{ }^{208} \mathrm{~Pb} / 206 \mathrm{~Pb}\right)$ and Muscat Ottonel variety from $2011(17.44513 \pm 0.03613$ $\left.[0.14977]{ }^{208} \mathrm{~Pb} /{ }^{206} \mathrm{~Pb}\right)$. While Feteasca Regala from $2012(2.12126 \pm 0.00106$ $\left.[0.05014]{ }^{208} \mathrm{~Pb} /{ }^{206} \mathrm{~Pb}\right)$, Feteasca Alba from $2013(17.30857 \pm 0.00560$ [0.03235] $\left.{ }^{206} \mathrm{~Pb} / 204 \mathrm{~Pb}\right)$, and also Cabernet Sauvignon from $2012(1.12545 \pm 0.00200$ $\left.[0.17771]{ }^{206} \mathrm{~Pb} / 207 \mathrm{~Pb}\right)$, recorded the lowest isotope ration.

The results are comparable with Brazilian wines [36] (2.0700 to 2.1570 for ${ }^{208} \mathrm{~Pb} /{ }^{206} \mathrm{~Pb}$ and 16.6670 to 17.9960 for ${ }^{204} \mathrm{~Pb} /{ }^{206} \mathrm{~Pb}$ ) and also with Italian wines [46] (2.0990 to 2.1030 for ${ }^{208} \mathrm{~Pb} /{ }^{206} \mathrm{~Pb}$ and 17.544 to 18.3210 for $\left.{ }^{204} \mathrm{~Pb} / 206 \mathrm{~Pb}\right)$. 


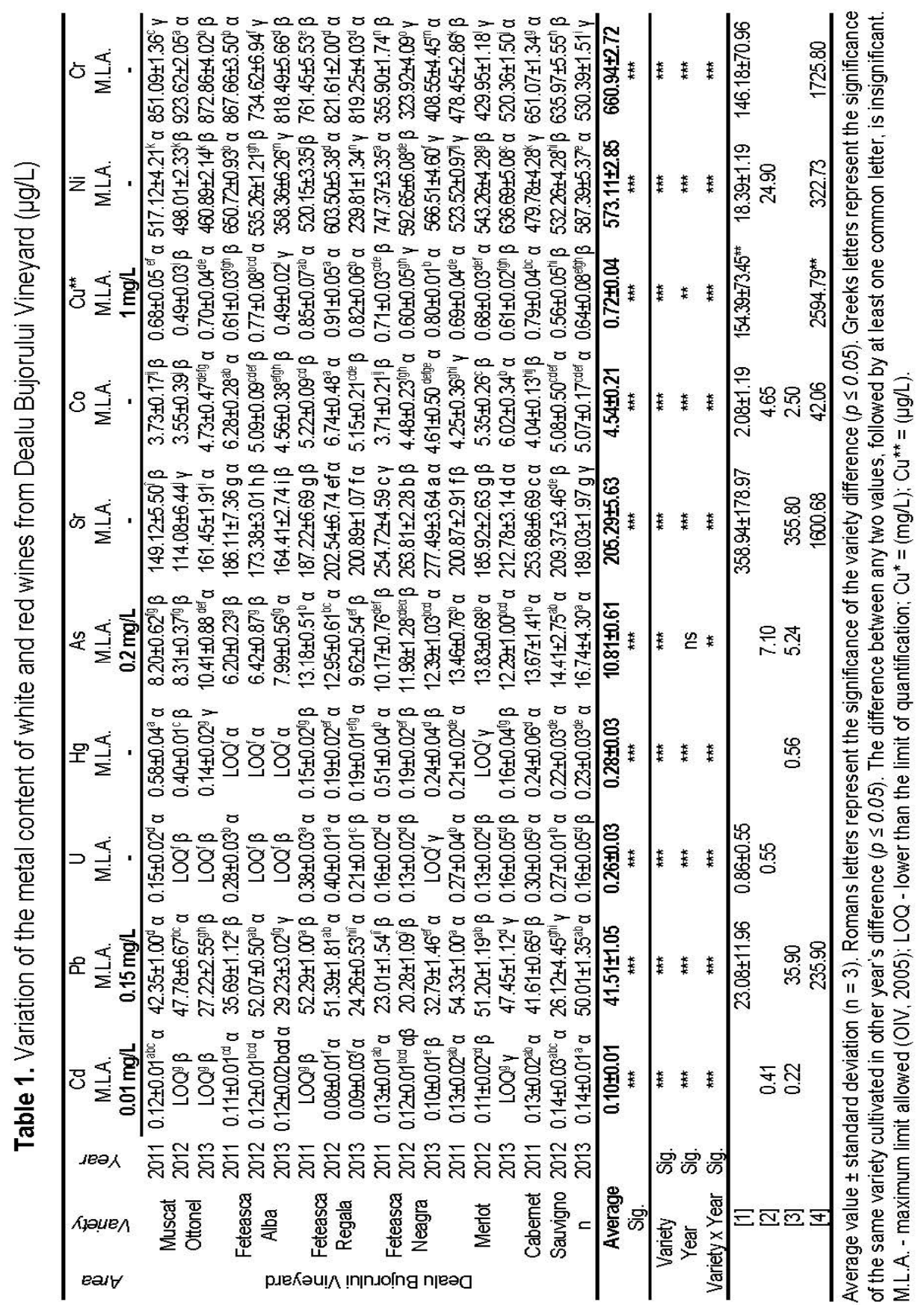


The abundance of the lead isotopes ${ }^{204} \mathrm{~Pb}$ (non-radiogenic), ${ }^{206} \mathrm{~Pb}$, ${ }^{207} \mathrm{~Pb}$ and ${ }^{208} \mathrm{~Pb}$ (radiogenic) originated from the genesis of the substrate varies with geological ages. The original composition of the rock upon its formation and consequently, with geographical areas [47], this property is useful in order to identify of the source of lead in a subjected wine sample provided that the measurements of the isotope ratio is precise and accurate.

Concerning ${ }^{87} \mathrm{Sr} / 86 \mathrm{Sr}$ isotope ratio, the values are between the ranges from $0.72599 \pm 0.00645[0.89970]$ to $0.71288 \pm 0.00048$ [0.03012] with an average value of $0.72158 \pm 0.00042$ [0.05763]. The highest values were registered to wine obtained from Fetească regala variety from 2011 $(0.72599 \pm 0.00422[0.58123])$, the lowest value of ${ }^{87} \mathrm{Sr} /{ }^{86} \mathrm{Sr}$ isotope ratio was recorded to wine obtained from 2012 Feteasca Alba variety $(0.71288 \pm 0.00098$ [0.13715]).

The values of ${ }^{87} \mathrm{Sr} /{ }^{86} \mathrm{Sr}$ isotope ratio obtained are comparable with those obtain for other Romanian wines [48] (0.71015 to 0.72311) and [20] (0.7600 to 0.9300$)$.

\section{Combining multielement analysis and ${ }^{206} \mathrm{~Pb} /{ }^{207} \mathrm{~Pb},{ }^{208} \mathrm{~Pb} /{ }^{06} \mathrm{~Pb}$, ${ }^{206} \mathrm{~Pb} /{ }^{204} \mathrm{~Pb},{ }^{87} \mathrm{Sr} /{ }^{66} \mathrm{Sr}$, isotope ratio from wine samples for discrimination analysis}

Multivariate chemometric method was used as a supervised learning technique for the differentiation of wines intro groups on the basis of grape variety and year of production and finding markers which showed a significant discrimination value (variables with Wilk's lambda near zero, $p$ value $<0.05$ and higher $F$ coefficients). Stepwise linear discriminant analysis (LDA) was used to identify significant tracers for classification to the geographical discrimination of the wines samples. Stepwise Discriminant Analysis (LDA) was used to designate suitable variables for classification of the samples, eliminating the variables that do not contribute to discrimination of the wine. In order to validate the proposed statistic model, based on variables which showed higher significance in first LDA assessment, we performed a second Liniar Discriminant Analysis (LDA) for the test set consisting of wines used to build statistical model (training set) together with data from other wine samples that are not included in the first LDA (control-set). Cross-validation was applied to determine the optimal number of variables required to obtain robust models.

In this study, the content of certain wines showed high concentration of metals, but not exceeding the maximum recommended by International Organisation of Vine and Wine [49]; this accumulation is mostly due to agricultural practices, fertilizers and technological winemaking processes. 


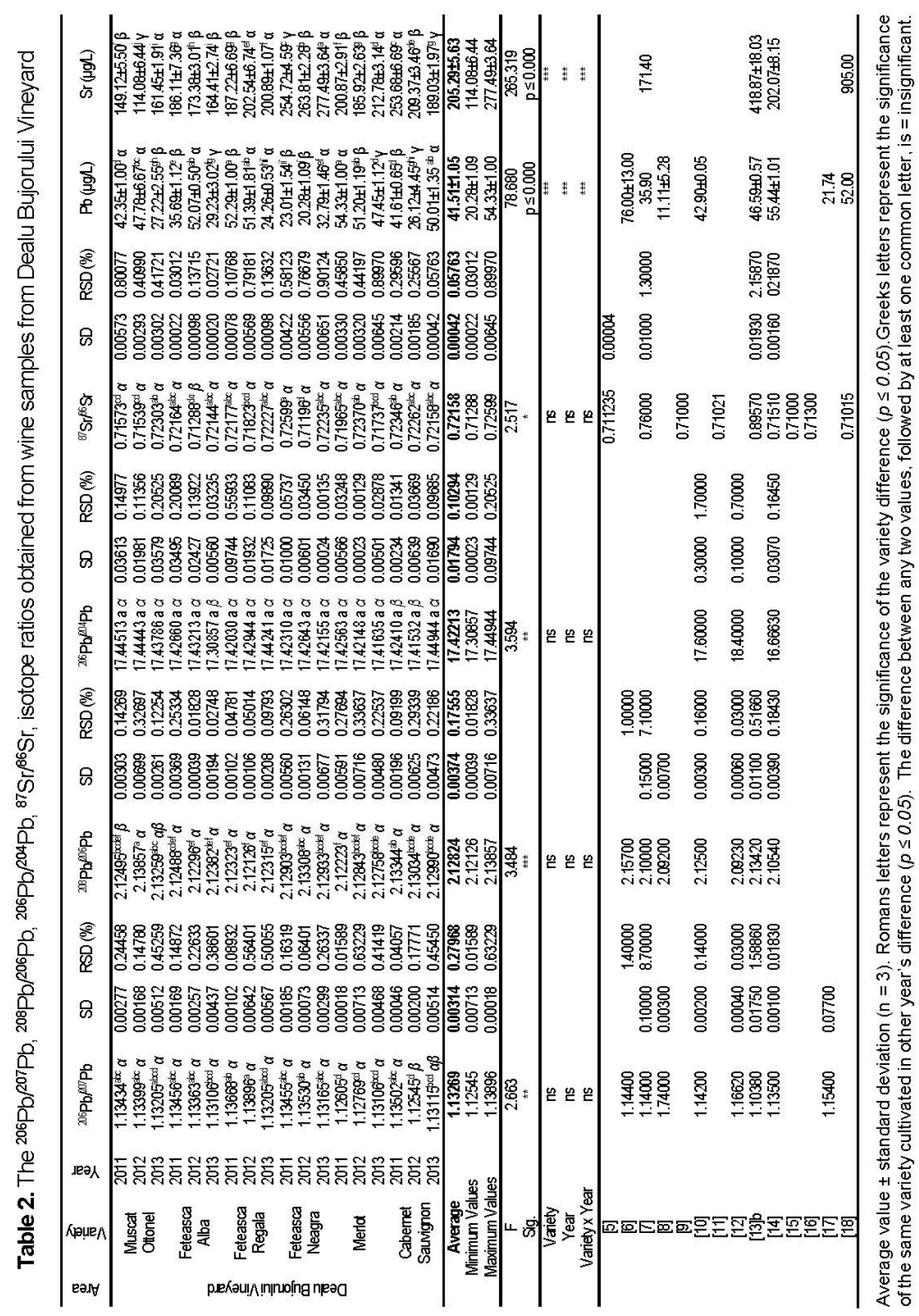




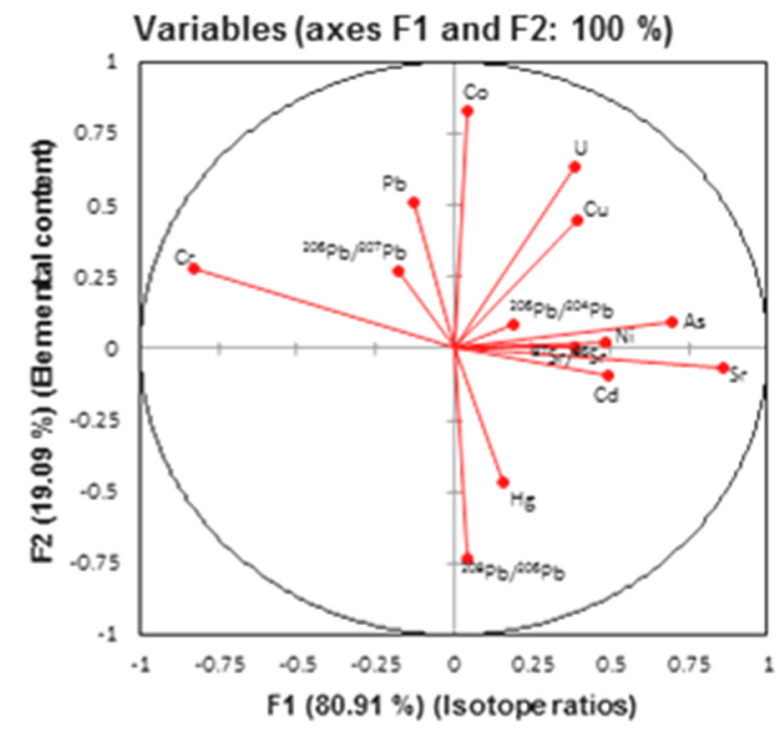

Figure 1. Correlation between analyzed parameters and the factors in discriminant analysis the origin of the wine

Observations (axes F1 and F2: $100 \%$ )

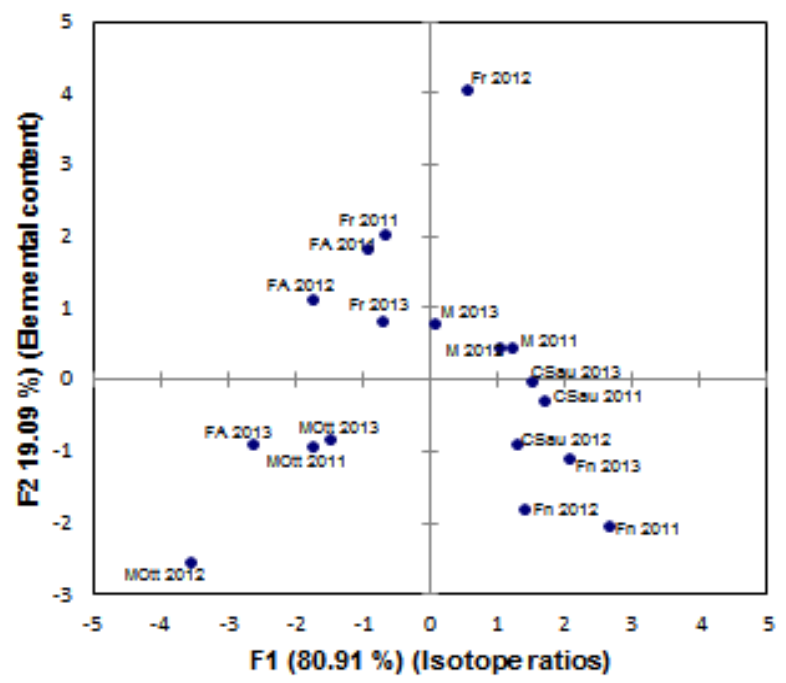

Figure 2. Differentiation of wines based on element contents and ${ }^{206} \mathrm{~Pb} /{ }^{207} \mathrm{~Pb}$, ${ }^{208} \mathrm{~Pb} /{ }^{206} \mathrm{~Pb},{ }^{206} \mathrm{~Pb} / 204 \mathrm{~Pb},{ }^{87} \mathrm{Sr} /{ }^{86} \mathrm{Sr}$ isotope ratios 
Elements like $\mathrm{Pb}, \mathrm{Cu}, \mathrm{Ni}, \mathrm{Cd}$ and $\mathrm{Hg}$ showed a high discriminatory power for geographic origin of Romanian, but additional new elements (Co, $\mathrm{U}$, As, Sr, Cr) and ${ }^{207} \mathrm{~Pb} /{ }^{206} \mathrm{~Pb},{ }^{208} \mathrm{~Pb} /{ }^{206} \mathrm{~Pb},{ }^{204} \mathrm{~Pb} /{ }^{206} \mathrm{~Pb},{ }^{87} \mathrm{Sr} /{ }^{86} \mathrm{Sr}$ isotope ratio have been investigated in order to identify new tracers for geographical traceability of Romanian wines [41].

Based on the elemental contents and ${ }^{207} \mathrm{~Pb} /{ }^{206} \mathrm{~Pb},{ }^{208} \mathrm{~Pb} /{ }^{206} \mathrm{~Pb}$, ${ }^{204} \mathrm{~Pb} / 206 \mathrm{~Pb},{ }^{87} \mathrm{Sr} /{ }^{86} \mathrm{Sr}$ isotopes ratio, the cross-validation technique provided a $100 \%$ percentage of predicted membership according to the origin of the wine $(\mathrm{F} 1=80.91 \%$ and $\mathrm{F} 2=19.09 \%)$. The linear correlation revealed acceptable scores for the two defined discriminant factors (F1 and F2) (Figure 1). A significant differentiation of wines according to the year of wine production was carried out for wines samples, which demonstrates the importance of elemental profile for the geographical traceability of wines (Figure 2).

\section{CONCLUSIONS}

In this work the elemental composition and ${ }^{207} \mathrm{~Pb} /{ }^{206} \mathrm{~Pb},{ }^{208} \mathrm{~Pb} /{ }^{206} \mathrm{~Pb}$, ${ }^{204} \mathrm{~Pb} / 206 \mathrm{~Pb},{ }^{87} \mathrm{Sr} /{ }^{86} \mathrm{Sr}$ isotope ratio of white wines (Muscat Ottonel, Feteasca Alba, Feteasca Regala) and red wines (Feteasca Neagra, Merlot, Cabernet Sauvignon) was studied in order to highlight the elemental composition of wine samples.

Concentration of $\mathrm{Cd}, \mathrm{Pb}, \mathrm{As}$ and $\mathrm{Cu}$ heavy metals in analysed wine samples were under Maximum Limit Allowed (M.L.A.), respectively as published by the Organization of Vine and Wine. The content of potentially toxic elements such as $\mathrm{Cd}, \mathrm{Pb}, \mathrm{U}, \mathrm{Hg}, \mathrm{As}, \mathrm{Cu}, \mathrm{Ni}$ and $\mathrm{Cr}$ are lower than the recommended values found in literature, highlighting the safety and quality of the analyzed Romanian wines.

Our results confirm that the ${ }^{207} \mathrm{~Pb} /{ }^{206} \mathrm{~Pb},{ }^{208} \mathrm{~Pb} /{ }^{206} \mathrm{~Pb},{ }^{204} \mathrm{~Pb} /{ }^{206} \mathrm{~Pb}$ and ${ }^{87} \mathrm{Sr} /{ }^{86} \mathrm{Sr}$ isotope ratio can be used to track the origin of wine, to discriminate between the wine produced in different years and can be used to characterize wine terroirs for forensic purpose. Based on the elemental profile and ${ }^{207} \mathrm{~Pb} /{ }^{206} \mathrm{~Pb},{ }^{208} \mathrm{~Pb} /{ }^{206} \mathrm{~Pb},{ }^{204} \mathrm{~Pb} /{ }^{206} \mathrm{~Pb},{ }^{87} \mathrm{Sr} /{ }^{86} \mathrm{Sr}$ isotope ratio, a relevant discrimination of wines according to the production year was performed. The variation of ${ }^{207} \mathrm{~Pb} /{ }^{206} \mathrm{~Pb},{ }^{208} \mathrm{~Pb} /{ }^{206} \mathrm{~Pb}$, ${ }^{204} \mathrm{~Pb} /{ }^{206} \mathrm{~Pb},{ }^{87} \mathrm{Sr} /{ }^{86} \mathrm{Sr}$ isotope ratio represents a strong geological marker for wines geographical traceability. The proposed methodology allowed successful classification of wines according to the region of provenance and also the production year. 


\section{EXPERIMENTAL SECTION}

\section{Study area}

A total of 54 wine samples were analysed ( 3 white wines and 3 red wines). Samples originated from Dealu Bujorului vineyard $\left(45^{\circ} 52^{\prime} 10^{\prime \prime} \mathrm{N}\right.$, $27^{\circ} 55^{\prime} 8$ "E). The Dealu Bujorului region is characterized by an alternate landscape, from flat to hilly areas, with altitude between 100 and $225 \mathrm{~m}$ and the predominant soil is levigated chernozem having a clayey sand texture with $\mathrm{pH}$ between values 7.4 and 8.1. Although they have moisture deficit, natural conditions (ecoclimatic and ecopedological) offer viable ecosystem for the development of vineyard. The vineyard is crossed by the parallel $46^{\circ}$ latitude north, intersected by the $28^{\circ}$ longitude meridian. Dealu Bujorului vineyard belongs to Galați country. The specificity of the transition area is highlighted by the predominance of deposits of clays and sands. Versants were made from clay deposits and sandy sands.

\section{Sample collection and microvinification process}

The samples used in this experiment were obtained from the wines produced from Muscat Ottonel, Feteasca Alba, Feteasca Regala, Feteasca neagra, Merlot and Cabernet Sauvignon under the conditions of 2011, 2012 and 2013. The wine samples resulted from micro-wine production. Microwine production was done according to the methodology describe by Bora et al. [12]. All wines were providing by the wineries as finished wines in 750 $\mathrm{mL}$ bottles with cork stoppers and were stored at $3-4^{\circ} \mathrm{C}$ before analysis. All vines were planted since 1979, and the vine plantation was organized with $2.2 \times 1 \mathrm{~m}$ distance between rows and plants. Vines were pruned according to the Guyot system and were grown on speliers.

\section{Reagents and solutions}

Ten elements ( $\mathrm{Cd}, \mathrm{Pb}, \mathrm{U}, \mathrm{Hg}, \mathrm{As}, \mathrm{Sr}, \mathrm{Co}, \mathrm{Cu}, \mathrm{Ni}$ and $\mathrm{Cr}$ ) were determined in order to assess their ability to discriminate wines by geographical origin. The analysis was made using multielement analysis and ICP-MS technique, after an appropriate dilution, using external standard calibration method. The calibration was performed using XXICertiPUR multielement standard, and from individual standard solution 
of $\mathrm{Cr}$ and $\mathrm{Hg}$. The working standards and the control sample were prepared daily from the intermediate standards that were prepared from the stock solution. The intermediate solutions stored in polyethylene bottles and glassware was cleaned by soaking in $10 \% \mathrm{v} / \mathrm{v} \mathrm{HNO}_{3}$ for 24 hours and rinsing at least ten rimes with ultrapure water $\left(18.2 \mathrm{M} \Omega \mathrm{cm}^{-1}\right.$ ultrapure water-Types 1). The accuracy of the methods was evaluated by replicate analyses of fortified samples (10 $\mu \mathrm{L}-10 \mathrm{~mL}$ concentrations) and the obtained values ranged between 0.8-13.1 percent, depending on the element. The global recovery for each element was estimated and the obtained values were between 84.6-100.9\% [48].

For quality control purpose, blanks and triplicates samples $(n=3)$ were analyzed during the procedure. The variation coefficient was under $5 \%$ and detection limits ( $\mathrm{ppb}$ ) were determined by the calibration curve method. Limit of detection (LoD) and Limit of quantification (LoQ) limits were calculated according to the next mathematical formulas: $L o D=3 S D / s$ and $\mathrm{LoQ}=10 \mathrm{SD} / \mathrm{s}$ (SD = estimation of the standard deviation of the regression line; $s=$ slope of the calibration curve) $($ Table 3$)$.

Table 3. Instrumental conditions for the determination of each element (ICP-MS technique)

\begin{tabular}{|c|c|c|c|c|}
\hline Element & $\begin{array}{c}\text { Correlation } \\
\text { coefficient }\end{array}$ & $\begin{array}{c}\mathrm{LoD}^{*} \\
(\mu \mathrm{g} / \mathrm{L})\end{array}$ & $\begin{array}{c}\mathrm{LoQ}^{* * *} \\
(\mu \mathrm{g} / \mathrm{L})\end{array}$ & $\begin{array}{c}\mathrm{BEC}^{* *} \\
(\mu \mathrm{g} / \mathrm{L})\end{array}$ \\
\hline $\mathrm{Cd}$ & 0.9999 & 0.0202 & 0.0673 & 0.027 \\
\hline $\mathrm{U}$ & 0.9999 & 0.0253 & 0.0842 & 0.005 \\
\hline $\mathrm{As}$ & 0.9999 & 0.2335 & 0.7776 & 0.538 \\
\hline $\mathrm{Co}$ & 0.9999 & 0.0365 & 0.1215 & 0.152 \\
\hline $\mathrm{Ni}$ & 0.9999 & 0.0591 & 0.1968 & 0.091 \\
\hline $\mathrm{Pb}$ & 0.9999 & 0.0003 & 0.0010 & 0.002 \\
\hline $\mathrm{Hg}$ & 0.9999 & 0.0417 & 0.1379 & 0.128 \\
\hline $\mathrm{Sr}$ & 0.9999 & 0.1434 & 0.4775 & 0.955 \\
\hline $\mathrm{Cu}$ & 0.9999 & 0.0402 & 0.1339 & 0.237 \\
\hline $\mathrm{Cr}$ & 0.9999 & 1.6630 & 5.5378 & 0.636 \\
\hline
\end{tabular}

*Detection limit; **Background equivalent concentration; ${ }^{* * *}$ Quantification limit.

For calibration and to verify the achieved accuracy and precision, ten NIST-SRM 987 and NIST-SRM 982 analysis results were pooled together with the calculated relative standard deviation presented in Table 4. Based on the obtained results, it was verified that, applying quadrupole ICP-MS, relative standard deviation and reproducibility of approximately $0.5 \%$ for ${ }^{87} \mathrm{Sr} /{ }^{86} \mathrm{Sr}$, ${ }^{206} \mathrm{~Pb} /{ }^{207} \mathrm{~Pb}$ and ${ }^{208} \mathrm{~Pb} /{ }^{206} \mathrm{~Pb}$ are feasible. The results were in agreement with those reported by $[48,50]$. 
Table 4. Lead isotopic ration and Lead isotopic ration determination precision and accuracy based on the NIST SRM 982 (Lead) NIST SRM 987 (Strontium) $(n=10)$

\begin{tabular}{|c|c|c|c|c|c|c|c|c|}
\hline Replicate & $\begin{array}{c}{ }^{207} \mathrm{~Pb} /{ }^{206} \mathrm{~Pb} \\
(\mathrm{a})\end{array}$ & $\begin{array}{c}\mathrm{RSD} \\
(\%)\end{array}$ & $\begin{array}{c}{ }^{208} \mathrm{~Pb} / 206 \mathrm{~Pb} \\
(\mathrm{~b})\end{array}$ & $\begin{array}{c}\mathrm{RSD} \\
(\%)\end{array}$ & $\begin{array}{c}{ }^{204} \mathrm{~Pb} /{ }^{206} \mathrm{~Pb} \\
(\mathrm{c})\end{array}$ & $\begin{array}{c}\mathrm{RSD} \\
(\%)\end{array}$ & $\begin{array}{c}{ }^{87} \mathrm{Sr} /{ }^{86} \mathrm{Sr} \\
(\mathrm{d})\end{array}$ & $\begin{array}{c}\mathrm{RSD} \\
(\%)\end{array}$ \\
\hline 1 & 0.46483 & 0.51 & 0.99891 & 0.67 & 0.00271 & 0.32 & 0.70493 & 0.31 \\
\hline 2 & 0.47891 & 0.48 & 0.99452 & 0.61 & 0.00272 & 0.41 & 0.72046 & 0.45 \\
\hline 3 & 0.46978 & 0.32 & 0.99794 & 0.55 & 0.00275 & 0.28 & 0.70325 & 0.63 \\
\hline 4 & 0.47123 & 0.64 & 0.99688 & 0.64 & 0.00273 & 0.51 & 0.70634 & 0.48 \\
\hline 5 & 0.46987 & 0.56 & 0.99726 & 0.48 & 0.00246 & 0.14 & 0.71478 & 0.36 \\
\hline 6 & 0.46154 & 0.37 & 0.99647 & 0.56 & 0.00258 & 0.39 & 0.71245 & 0.59 \\
\hline 7 & 0.47362 & 0.70 & 0.99969 & 0.34 & 0.00279 & 0.47 & 0.70987 & 0.46 \\
\hline 8 & 0.45641 & 0.43 & 0.99744 & 0.58 & 0.00278 & 0.51 & 0.72326 & 0.42 \\
\hline 9 & 0.41562 & 0.36 & 0.99576 & 0.59 & 0.00273 & 0.49 & 0.70845 & 0.68 \\
\hline 10 & 0.45612 & 0.45 & 0.99874 & 0.61 & 0.00278 & 0.36 & 0.10789 & 0.47 \\
\hline Average & 0.46179 & 0.48 & 0.99736 & 0.56 & 0.00270 & 0.41 & 0.71117 & 0.49 \\
\hline
\end{tabular}

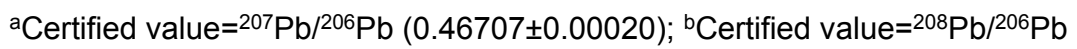

(1.00016 \pm 0.00036$)$; ${ }^{\circ}$ Certified value $={ }^{204} \mathrm{~Pb} / 206 \mathrm{~Pb}(0.027219 \pm 0.00027)$; ${ }^{\mathrm{d}}$ Certified value $={ }^{87} \mathrm{Sr} /{ }^{86} \mathrm{Sr}(0.71034 \pm 0.00026) ; \mathrm{RSD}(\%)=$ relative standard deviation.

\section{Sample preparation for determination of heavy metals and isotopic ration from wine using ICP-MS.}

For the determination of elements from wine samples were used an amount of $0.5 \mathrm{~mL}$ wine and adjust $8 \mathrm{~mL}\left(7 \mathrm{~mL} \mathrm{HNO} \mathrm{HN}_{3} 65 \%+1 \mathrm{~mL} \mathrm{H}_{2} \mathrm{O}_{2}\right)$ were placed in a clean Teflon digestion vessel, after 15-30 minutes the mineralization was performed using a microwave system Milestone START D Microwave Digestion System set in three steps: step I (time $10 \mathrm{~min}$., temperature $200^{\circ} \mathrm{C}$ ), step II (time 15 min., temperature $200^{\circ} \mathrm{C}$ ) and step III (time 40 min., ventilation temperature $32^{\circ} \mathrm{C}$ ). After mineralization, samples were filtered through a 0.45 $\mathrm{mm}$ filter and brought to a volume of $50 \mathrm{~mL}$. The $\mathrm{Pb}$ and $\mathrm{Sr}$ isotope ration in the analysed wine samples $\left({ }^{206} \mathrm{~Pb} /{ }^{207} \mathrm{~Pb},{ }^{208} \mathrm{~Pb} /{ }^{206} \mathrm{~Pb},{ }^{206} \mathrm{~Pb} / 204 \mathrm{~Pb},{ }^{87} \mathrm{Sr} /{ }^{86} \mathrm{Sr}\right.$, ) were determined according to the methodology indicated by Mihaljevič et al. [51]; Geana et al. [21]; Bora et al. [24].

In order to confirm the best-chosen conditions for wine digestion standard additions for checking accuracy of the microwave digestion and recoveries were calculated (Table 5). The digestion seemed visually completed in all of the combinations, but the spiked recoveries showed significant differences for total elements content $(p-$ Value $=0.005)$. 
Table 5. Standard additions for checking accuracy of the microwave digestion ICP-MS method $(n=3)$

\begin{tabular}{|c|c|c|}
\hline Element & $\begin{array}{c}\text { Certified Concentration } \\
(\mathrm{mg} / \mathrm{L})\end{array}$ & $\begin{array}{c}\text { Measured Concentration } \\
(\mathrm{mg} / \mathrm{L})\end{array}$ \\
\hline $\mathrm{Cd}$ & $6.568 \pm 0.073$ & $6.473 \pm 0.106$ \\
\hline $\mathrm{U}$ & $9.994 \pm 0.016$ & $9.981 \pm 0.012$ \\
\hline $\mathrm{As}$ & $56.85 \pm 0.37$ & $53.09 \pm 0.31$ \\
\hline $\mathrm{Co}$ & $27.06 \pm 0.28$ & $24.13 \pm 0.06$ \\
\hline $\mathrm{Ni}$ & $62.41 \pm 0.69$ & $61.32 \pm 0.21$ \\
\hline $\mathrm{Pb}$ & $19.63 \pm 0.21$ & $19.13 \pm 0.09$ \\
\hline $\mathrm{Hg}$ & $0.1016 \pm 0.0017$ & $0.1102 \pm 0.0012$ \\
\hline $\mathrm{Sr}$ & $314.00 \pm 19.00$ & $314.09 \pm 09.06$ \\
\hline $\mathrm{Cu}$ & $21.44 \pm 0.70$ & $21.25 \pm 0.21$ \\
\hline $\mathrm{Cr}$ & $18.32 \pm 0.10$ & $19.18 \pm 0.21$ \\
\hline
\end{tabular}

\section{Instrumentation}

The determination of metals was performed on mass spectrometer with inductively coupled plasma, (ICP-MS) iCAP Q Thermo scientific model, based polyatomic species before they reach the quadrupole mass spectrometer, using a PFA micro flow concentric nebulizer. The argon used was of $99.99 \%$ purity (Messer, Austria). The instrument was daily optimized to give maximum sensitivity for $\mathrm{M}^{+}$ions and the double ionization and oxides monitored by the means of the rations between $\mathrm{Ba}^{2+} / \mathrm{Ba}^{+}$and $\mathrm{Ce}^{2+} / \mathrm{CeO}^{+}$, respectively, these always being less than $2 \%$. The experimental conditions were: argon flow on nebulizer ( $0.82 \mathrm{~L} / \mathrm{min}$.), auxiliary gas flow $0.80 \mathrm{~L} / \mathrm{min}$., argon flow in plasma $15 \mathrm{~L} / \mathrm{min}$., lens voltage $7.30 \mathrm{~V}$; RF power in plasma 1100 $\mathrm{W}$, spray chamber temperature $\left(2.50 \pm 1.00^{\circ} \mathrm{C}\right)$. Accuracy was calculated for the elements taken into consideration (0.5-5.0\%).

\section{Statistical analysis}

The statistical interpretation of the results was performed using the Duncan test, SPSS Version 24 (SPSS Inc., Chicago, IL., USA). The statistical processing of the results was primarily performed in order to calculate the following statistical parameters: average and standard deviation. This data was interpreted with the analysis of variance (ANOVA) and the average separation was performed with the DUNCAN test at $p \leq$ 0.05 . Multivariate chemometric method was used as a supervised learning technique for the differentiation of wines intro groups on the basis of grape variety and year of production and finding markers which showed a 
significant discrimination value (variables with Wilk's lambda near zero, $p$ value $<0.05$ and higher $F$ coefficients). Stepwise linear discriminant analysis (LDA) was used to identify significant tracers for classification to the geographical discrimination of the wines samples. Stepwise Discriminant Analysis (LDA) was used to designate suitable variables for classification of the samples, eliminating the variables that do not contribute to discrimination of the wine. In order to validate the proposed statistic model, based on variables which showed higher significance in first LDA assessment, we performed a second Linear Discriminant Analysis (LDA) for the test set consisting of wines used to build statistical model (training set) together with data from other wine samples that are not included in the first LDA (control-set). Cross-validation was applied to determine the optimal number of variables required to obtain robust models. Linear discriminant analysis (LDA) was performed using Microsoft Excel 2016 and XLSTAT Addinsoft version 15.5.03.3707.

\section{ACKNOWLEDGMENTS}

This paper was published under the frame of the Romanian Ministry of Agriculture and Rural Development, project ADER no. 14.2.2. "Quantitative studies on assessment and monitoring contaminants, on the chain of viticulture and winemaking to minimize the amount of pesticides and heavy metals as principal pollutants".

\section{REFERENCES}

1. OIV, International Code of Oenological Practices, Annex: Maximum Acceptable Limits, 2015, Issue 2015/01. Paris, France.

2. F. Stoica, Carpathian Journal of Food Science and Technology, 2015, 7(4), 139-144.

3. G.L. La Torre, R. Rando, M. Saitta, M. Alfa, R. Malsano, G. Dugo, Italian Journal of Food Science, 2010,1(22), 28-40.

4. Y. Vystavna, L. Zaichenko, L. Klimenko, R. Ratsep, Journal of Science Food and Agriculture, 2017, 97, 4520-4525.

5. J. Halili, K. Bislimi, I. Mazreku, A. Behluli, F. Osmani, A. Maloku, F. Halili, 13th SGEM GeoConference on Ecology, Economics, Education and Legislation, Conference Proceedings, 2013, 1, 531- 538. 
6. M.D. Blackhurst, A.D. Marais, Journal of Endocrinology, Metabolism and Diabetes of South Africa, 2009, 44(2), 77-79.

7. I.M. Alkis, S. Oz, A. Akatol, N. Yilmaz, R. E. Anli, O. Akatol, Journal of Food Compostion and Analysis, 2014, 33, 105-110.

8. S. Đurđic, M. Pantelic, J. Trifkovic, V. Vukojevic, M. Natic, 'Z. Tesica, J. Mutic, RSC Advances, 2017, 7, 2151-2162.

9. I. Geană, A. Iordache, R. Ionete, A. Marinescu, A. Ranca, M. Culea, Food Chemistry, 2013, 138, 1125-1134.

10. M. A. I. Chukwujindu, A. L. Ojelum, F. I. Bassey, Food Science and Nutrition, 2014, 2(6): 724-733.

11. K. Pyrzynska, Critical Reviews in Analytical Chemistry, 2004, 34, 69-83.

12. F. D. Bora, A. Donici, C. Voica, T. Rusu, L. Mihaly-Cozmuța, A. MihalyCozmuța, C. Cimpoiu, D. E. Mihăiescu, Advances in Agriculture and Botanics - International Journal of the Bioflux Society, 2016, 8(3), 129-142.

13. K. M. Towle, L. C. Garnick, A. D. Monnot, International Journal of Food Contamination, 2017, 4:7.

14. P. Hajeb, J. J. Sloth, S. Shakibazadeh, N. A. Mahyudin, L. Afsah-Hejri, Comprehensive Reviews in Food Science and Food Safety, 2014, 13, 457-472.

15. J. Cacho, J. E. Castells, A. Esteban, B. Laguna, N. Sagrista, American Journal of Enology and Viticulture, 1995, 46, 381-384.

16. K. A. Riganakos, P.G. Veltsistas, Food Chemistry, 2003, 82, 637-643.

17. P. Bentez, R. Castro, J.A. S. Pazo, C.G. Barroso, Food Research International, 2002, 35, 785-791.

18. A.D. Monnot, B.E. Tvermoes, R. Gerads, H. Gürleyük, D. Paustenbach, Food Chemistry, 2016, 211, 107-113.

19. S. Ražić, A. Onjia, American Journal of Enology and Viticulture, 2010, 61(4), 506-511.

20. V. Avram, C. Voica, A. Hosu, C. Cimpoiu, C. Măruțoiu, Revue Roumaine de Chimie, 2014, 59(11-12), 1009-1019.

21. L. Järup, British Medical Bulletin, 2003, 68 (1), 167-182.

22. V. Orescanin, A. Katunar, A. Kutle, V. Valkovic, Journal of Trace and Microprobe Tehniques Trace Bioelements, 2003, 21(1), 171-180.

23. S. Catarino, M. Madeira, F. Monteiro, F. Rocha, A. S. Curvelo-Garcia, R. Bruno De Sousa, Journal of Agricultural and Food Chemistry, 2008, 56, 158-165.

24. F. D. Bora, A. Donici, T. Rusu, A. Bunea, D. Popescu, C. I. Bunea, Notulae Botanicae Horti Agrobotanicae, 2018, 46(1), 223-239.

25. B. Médina, S. Augagneur, M. Barbaste, F.E. Grousset, P.I. Buat-Ménard, Food Additives and Contaminants, 2000, 17(6), 435-445.

26. R. Larcher, G. Nicolini, P. Pangrazzi, Journal of Agricultural and Food Chemistry, 2003, 51(20), 5956-5961.

27. M. Mihaljevic, V. Ettler, O. Sebek, L. Strnad, V. Chrastny, Journal of Geochemistry Exploration, 2006, 88, 130-133.

28. B.L. Gulson, T.H. Lee, K.J. Mizon, M.J. Korsch, H.R. Eschnauer, American Journal of Enology and Viticulture, 1992, 43, 180-190. 
29. C.M.R. Almeida, M.T.S.D. Vasconcelors, Journal of Agricultural and Food Chemistry, 2003, 51, 4788-4798.

30. C.M.R. Almeida, M.T.S.D. Vasconcelors, Food Chemistry, 2004, 85, 7-12.

31. F.D. Bora, A. Donici, A. Călugăr, I.V. Petrescu Mag, E. Gál, C.I. Bunea, Studia UBB Chemia, 2017, LXII, 4, Tom II, 317-332.

32. S. Marchionni, A. Buccianti, A. Bollati, E. Braschi, F. Cifelli, P. Molin, M, Paratto, M. Mattei, S. Tommasini, S. Conticelli, Food Chemistry, 2016, 190, 777-785.

33. I. Tescione, S. Marchionni, M. Mattei, F. Tassi, C. Romano, S. Conticelli, Procedia Earth Planetary Science, 2015, 13, 169-172.

34. E. Tatár, V. G. Mihucz, I. Virág, L. Rácz, G. Záray, Microchemistry Journal, 2007, 85, 132-135.

35. A. Deheleanu, C. Voica, Romanian Journal of Physics, 2012, 57(7-8), 1194-1203.

36. C. M. S. Almeida, A. C. Almeida, M. L. D. P. Godoy, T. D. Saint'Pierre, J. M. Godoy, Journal of Brazilian Chemistry Society, 2016, 27(6), 1026-1031.

37. V. Ivanova-Petropulos, H. Wiltsche, T. Stafilov, M. Stefova, H. Motter, E. Lankmayr, Macedonian Journal of Chemistry and Chemistry Engineering, 2013, 32(2), 265-281.

38. V. Ivanova-Petropulos, B. Balavanova, S. Mitrev, D. Nedelkovski, V. Dimovska, R. Gulaboski, Food Analytical Methods, 2016, 9(1), 48-60.

39. F. Galgano, F. Favati, M. Caruso, T. Scarpa, A. Palma, Food Science and Technology, 2008, 41, 1808-1815.

40. D. Karataș, F. Aydin, I. Aydin, H. Karataș, Czech Journal of Food Science, 2015, 33(3), 228-236.

41. E. I. Geana, A. Marinescu, A. M. Iordache, C. Sandru, R. E. Ionete, C. Bala, Food Analytical Methods, 2014, 48(2), 2064-2074.

42. D. Schiavo, I.Y. Neira, I.A. Nóbrega, Talanta, 2008, 76, 1113-1118.

43. Z. Ajtony, N. Szoboszlai, E.K. Suskó, P. Mezei, K. György, L. Bencs, Talanta, 2008, 76, 627-634.

44. G. Dugo, L. La Pera, T.M Pellicanó, G. Di Bella, M. D'Imperio, Food Chemistry, 2005, 91, 355-363.

45. S. Galani-Nikolakaki, N. Kallithrakas-Kontos, A.A. Katsanos, Science of the Total Environment, 2002, 285, 155-163.

46. M. Barbaste, L. Halicz, A. Galy, B. Medina, H. Emteborg, F. C. Adams, R. Lobinski, Talanta, 2001, 54, 307-317.

47. B.L. Gulson, T.H. Lee, K.J. Mizon, M.J. Korsch, H.R. Eschnauer, American Journal of Enology and Viticulture, 1992, 43, 180-190.

48. E.I. Geană, C. Sandru, V. Stanciu, R.E. Ionete, Food Analytical Methods, 2017, 10(1), 63-73.

49. OIV. Maximum acceptable limits of various substances contained in wine. In: OIV Editor. Compendium of international methods of analysis of wine and must analysis. Place: Paris (Pa); 2016.

50. M. Barbaste, K. Robinson, S. Guilfoyle, B. Medina, R. Lobinsky, Journal of Analytical Atomic Spectrometry, 2002, 17, 135-137. 